\title{
Thyroid dysfunction, either hyper or hypothyroidism, promotes gallstone formation by different mechanisms*
}

\author{
Yong $\mathrm{WANG}^{\S 1}$, Xing YU ${ }^{\S 2}$, Qun-zi ZHAO ${ }^{\dagger 1}$, Shu ZHENG ${ }^{\dagger 2}$, \\ Wen-jie QING $^{3}$, Chun-di MIAO ${ }^{3}$, Jaiswal SANJAY ${ }^{3}$ \\ ( ${ }^{1}$ Department of Thyroid Surgery, the Second Affiliated Hospital, School of Medicine, Zhejiang University, Hangzhou 310009, China) \\ $\left({ }^{2}\right.$ Cancer Institute, the Second Affiliated Hospital, School of Medicine, Zhejiang University, Hangzhou 310009, China) \\ $\left({ }^{3}\right.$ Department of Clinical Medicine, School of Medicine, Zhejiang University, Hangzhou 310029, China) \\ †E-mail: zqz0167@gmail.com; zhengshu@zju.edu.cn
}

Received Sept. 3, 2015; Revision accepted Feb. 14, 2016; Crosschecked June 18, 2016

\begin{abstract}
We have investigated comprehensively the effects of thyroid function on gallstone formation in a mouse model. Gonadectomized gallstone-susceptible male C57BL/6 mice were randomly distributed into three groups each of which received an intervention to induce hyperthyroidism, hypothyroidism, or euthyroidism. After 5 weeks of feeding a lithogenic diet of $15 \%(\mathrm{w} / \mathrm{w})$ butter fat, $1 \%(\mathrm{w} / \mathrm{w})$ cholesterol, and $0.5 \%(\mathrm{w} / \mathrm{w})$ cholic acid, mice were killed for further experiments. The incidence of cholesterol monohydrate crystal formation was $100 \%$ in mice with hyperthyroidism, $83 \%$ in hypothyroidism, and $33 \%$ in euthyroidism, the differences being statistically significant. Among the hepatic lithogenic genes, $\operatorname{Tr} \beta$ was found to be up-regulated and $R x r$ down-regulated in the mice with hypothyroidism. In contrast, Lxra, Rxr, and Cyp7a1 were up-regulated and Fxr down-regulated in the mice with hyperthyroidism. In conclusion, thyroid dysfunction, either hyperthyroidism or hypothyroidism, promotes the formation of cholesterol gallstones in C57BL/6 mice. Gene expression differences suggest that thyroid hormone disturbance leads to gallstone formation in different ways. Hyperthyroidism induces cholesterol gallstone formation by regulating expression of the hepatic nuclear receptor genes such as $L x r \alpha$ and $R x r$, which are significant in cholesterol metabolism pathways. However, hypothyroidism induces cholesterol gallstone formation by promoting cholesterol biosynthesis.
\end{abstract}

Key words: Hypothyroidism, Hyperthyroidism, Cholesterol gallstone, C57BL/6 mice, Hepatic lithogenic genes http://dx.doi.org/10.1631/jzus.B1500210 CLC number: R653

\section{Introduction}

Gallstone disease is one of the most common gastrointestinal diseases requiring hospitalization in the West (Portincasa et al., 2006). The estimated prevalence of gallstones is $10 \%-15 \%$ in the general population (Diehl, 1991). Cholesterol gallstones, whose content is $>50 \%$ cholesterol, are responsible

\footnotetext{
Corresponding authors

${ }^{\S}$ The two authors contributed equally to this work

* Project supported by the National Natural Science Foundation of China (No. 81001084)

(1) ORCID: Yong WANG, http://orcid.org/0000-0002-9154-9781

(c) Zhejiang University and Springer-Verlag Berlin Heidelberg 2016
}

for $90 \%$ of all gallstones in Western countries (Attili et al., 1995; 1997) and about $77 \%$ in China (Wang et al., 2007).

The major events leading to the disease include supersaturation of bile with cholesterol, rapid precipitation of cholesterol crystals in the gallbladder, increased bile salt hydrophobicity, and inflammation of the gallbladder (Moschetta et al., 2004). Of these events, precipitation of cholesterol crystals from supersaturated bile is thought to be a prerequisite for gallstone formation: cholesterol crystals in bile are found in $70 \%$ of patients with "idiopathic" acute pancreatitis (Admirand and Small, 1968; Ros et al., 1991). In mice, cholesterol gallstones can be induced 
by feeding them a lithogenic diet containing cholesterol and cholic acid: the susceptible $\mathrm{C} 57 \mathrm{~L}$ strain is always used to establish gallstone animal models (Tepperman et al., 1964; van Erpecum et al., 2001).

The link between thyroid disease and lipid disorders has been known for a long time (Duntas, 2002) The composition and transport of lipoproteins can be seriously affected in thyroid disease. Hypothyroidism is associated with hypercholesterolemia causing increased concentrations of total and low-density lipoprotein (LDL) cholesterols. Hyperthyroidism is associated with lower total, LDL, and high-density lipoprotein (HDL) cholesterol levels and promotion of the reverse cholesterol transport (RCT) pathway (Pedrelli et al., 2010). Previous studies have shown a possible association between hypothyroidism and cholesterol gallstone disease (CGD) in human beings because of decreased fractional clearance of LDL by a reduced number of LDL receptors in the liver, low bile flow, and sphincter of Oddi dysfunction (Inkinen et al., 2001; Volzke et al., 2005; Cakir et al., 2009; Bonde et al., 2012). Several hepatic lithogenic genes have been identified in mice that are associated with the formation of cholesterol gallstones including increased biliary cholesterol secretion and saturation (Portincasa et al., 2006; Galman et al., 2008). However, it has not yet been determined whether hypothyroidism has an effect on the expression of these genes. Hypothyroidism may result in delayed emptying of the biliary tract due to the absence or weakness of the pro-relaxing effect of thyroxine on the sphincter of Oddi, which expresses thyroid hormone receptors $\beta 1$ and $\beta 2$. This causes subjects to be prone to gallstone formation (Inkinen et al., 2001; Laukkarinen et al., 2002; 2003).

Although several studies have found possible associations between hypothyroidism and CGD development, the underlying mechanism is still unclear (Laukkarinen et al., 2003; Cakir et al., 2009; Bonde et al., 2012). We conducted this study using animal models to further understand the relationship between thyroid dysfunction and CGD development. Unlike previous studies, we focus not only on the relationship between hypothyroidism and CGD, but also on hyperthyroidism and CGD. To our knowledge, no previous study has focused on the potential effect of hyperthyroidism on gallstone formation in vivo.

\section{Materials and methods}

\subsection{Animals}

Gallstone-susceptible C57BL/6 mice, male, aged 6 weeks, were purchased from the Jackson Laboratory (Nashville, USA). The research was conducted in conformity with the Public Health Service (PHS) Policy on Humane Care and Use of Laboratory Animals. All animal handling protocols were approved by the Animal Research Ethics Committees of the Second Affiliated Hospital, School of Medicine, Zhejiang University (Hangzhou, China). All efforts were made to minimize the number of animals and their suffering.

\subsection{Gonadectomy}

Animals were surgically orchidectomized through gonadectomy to avoid potential interference by testosterone-involved in hormone interaction. Following anesthesia, gonadectomy was performed by a small cranial pubic incision and removal of both testicles (Gililland and Finn, 2007). Then, muscle and fascia were closed using surgical silk, and the overlying skin was sutured. All animals recovered soon after surgery.

\subsection{Establishing mouse models for hypothyroid- ism, hyperthyroidism, and euthyroidism}

Gonadectomized animals (6 weeks C57BL/6 mice) were randomized into three groups: hypothyroidism group (subtotal thyroidectomy+phosphate buffer saline (PBS) injection), hyperthyroidism group (sham surgery+triiodothyronine (T3; 3,3',5-triiodoL-thyronine sodium salt, Sigma, Santa Cruz, CA, USA) injection), and euthyroidism group (sham surgery+PBS injection). Hypothyroidism was induced by subtotal thyroidectomy, and hyperthyroidism was induced by subcutaneous injection of sterile triiodothyronine.

Specifically, in the hypothyroidism group, mice underwent subtotal thyroidectomy plus PBS injection. The procedure for subtotal thyroidectomy was as follows: after anesthesia and depilation, animals were placed in the supine position with the neck elevated by rolled-up gauze. An anterior neck incision was made vertically. Parotid glands were separated laterally while gently grasping with non-traumatic forceps (Fig. 1a). Strap muscles were retracted laterally and held by retractors. Thyroid glands were usually 
located between the cricoid cartilage and the first four tracheal rings. Bilateral lobes of the thyroid were gently excised leaving the transparent isthmus in situ. The surgical specimens were fixed in $10 \%(\mathrm{v} / \mathrm{v})$ formalin and processed for histological analysis (Figs. 1b and 1c). After surgery, mice received subcutaneous injection of PBS at a dose of $2 \mu \mathrm{g} /$ body per $3 \mathrm{~d}$.

In the hyperthyroidism group, mice underwent the same preparation and dissection, but no thyroid tissue was resected. After this sham surgery, the mice received subcutaneous injection of $\mathrm{T} 3$ at a dose of $2 \mu \mathrm{g} /$ body per $3 \mathrm{~d}$.
In the euthyroidism group, mice underwent sham surgery plus subcutaneous PBS injection at the equivalent dose as mice in the hypothyroidism group.

\subsection{Diets}

After surgery, animals were housed in a temperature-controlled room $\left(22-23{ }^{\circ} \mathrm{C}\right)$ with a $12-\mathrm{h}$ light/12-h dark cycle and maintained on a low cholesterol $(0.02 \%(\mathrm{w} / \mathrm{w}))$ chow diet until 8 weeks of age, followed by a lithogenic diet containing $15 \%(\mathrm{w} / \mathrm{w})$ butter fat, $1 \%(\mathrm{w} / \mathrm{w})$ cholesterol, $0.5 \%(\mathrm{w} / \mathrm{w})$ cholic
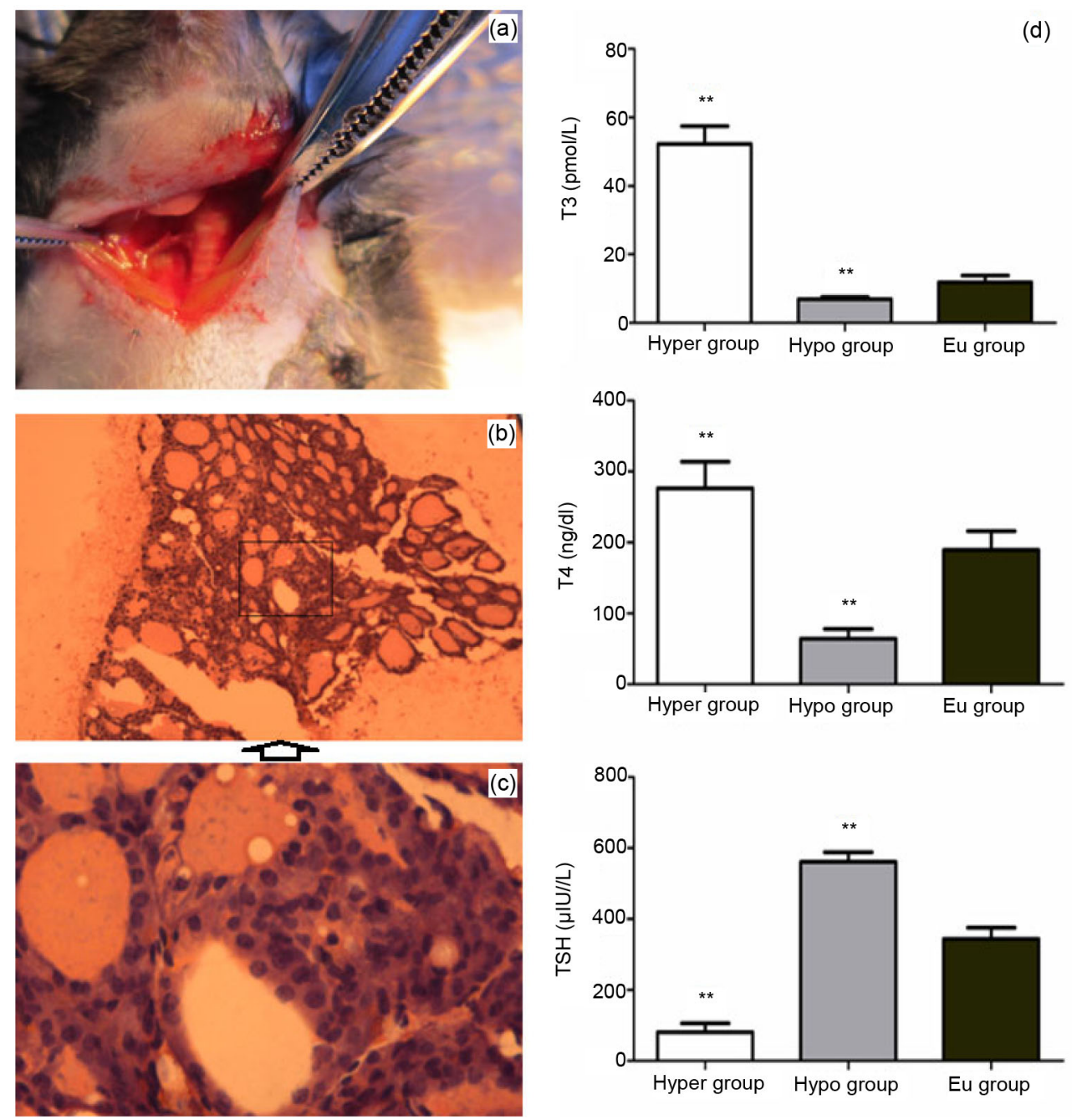

Fig. 1 Establishment of a hypothyroidism mouse model (a) and freshly excised thyroids observed under a light microscope $(b, c)$

(a) Mice underwent subtotal thyroidectomy. (b) Numerous colloid-containing follicles of varying sizes lined by epithelial cells were observed (hematoxylin/eosin staining, magnification 100×). (c) The stromal structures were visible between the colloids (hematoxylin/eosin staining, magnification 500×). (d) Comparison of triiodothyronine (T3), thyroxine (T4), and thyroid-stimulating hormone (TSH) levels of mice in the hyperthyroidism or hypothyroidism groups with those of mice in the euthyroidism group. All data were expressed as mean $\pm \mathrm{SD}$ ( $n=6$ animals in each group). ${ }^{* *} P<0.01$ vs. euthyroidism group 
acid, $2 \%(\mathrm{w} / \mathrm{w})$ corn oil, $50 \%(\mathrm{w} / \mathrm{w})$ sucrose, $20 \%$ $(\mathrm{w} / \mathrm{w})$ casein and essential minerals and vitamins. This diet has been shown previously to induce precipitation of cholesterol monohydrate crystals in susceptible strains of inbred mice (Khanuja et al., 1995; Wang et al., 1997).

\subsection{Examinations, measurements, and microscopic studies}

The body weight of each animal was measured every $3 \mathrm{~d}$ whilst they were on the lithogenic diet. At the end of each week until the tenth week of the diet, animals were killed after fasting for $12 \mathrm{~h}$, cholecystectomies were performed (six mice from each group at each time point) and gallbladder bile was collected through a small hole made at the fundus of the gallbladder with an 18-gauge needle. The bile was observed immediately using polarizing light microscopy for the presence of mucin strands, liquid and solid crystals, and sandy and true gallstones. Mucin was observed as non-birefringent amorphous strands. Arc-like, helical, tubular crystals, plate-like cholesterol monohydrate (ChM) crystals as well as small, aggregated, and fused liquid crystals were defined according to a previous study by Wang and Carey (1996). Sandy stones, which were irregularly shaped, were easily disintegrable agglomerates of $\mathrm{ChM}$ crystals embedded in mucin gel. As visualized under the microscope, individual cholesterol monohydrate crystals projected clearly from the edges of sandy stones, macroscopically displaying a yellow color. True gallstones were hard, ball-like objects with smooth curved surfaces. Because of scattered and absorbed light, they were opaque and black in color when observed using polarizing light microscopy.

Blood was collected from mouse orbital sinus just prior to euthanization and serum was obtained from the whole blood sample after centrifugation at $3300 \mathrm{~g}$ for $20 \mathrm{~min}$ at $4{ }^{\circ} \mathrm{C}$. Bile was stored at $-20{ }^{\circ} \mathrm{C}$, and serum samples, livers, and gallbladders were stored at $-80^{\circ} \mathrm{C}$ until further analyses.

Serum cholesterol levels were determined using a mouse cholesterol kit. Serum T3, thyroxine (T4), and thyroid-stimulating hormone (TSH) levels were determined using mouse enzyme-linked immunosorbent assay (ELISA) kits following the manufacturer's protocols.

RNA was extracted from frozen livers using TRIzol Reagent (Invitrogen, Carlsbad, CA, USA).
Reverse transcriptions were carried out with the iScript cDNA synthesis kit (Bio-Rad, Berkeley, CA, USA), according to the manufacturer's instruction. Real-time polymerase chain reaction (RT-PCR) was performed with $\mathrm{iQ}^{\mathrm{TM}}$ SYBR Green Supermix (Bio-Rad, Berkeley, CA, USA) using the 7900HT Fast Real-Time PCR System (Applied Biosystems, Foster City, CA, USA). Eight crucial hepatic lithogenic genes ( $T r \beta, R x r, L x r \alpha, R x r, C y p 7 \alpha 1, F x r, A b c g 5$, $A b c g 8)$ that have been reported to be associated with cholesterol gallstone susceptibility were studied to explore the genetic effects on gallstone formation in mice with different thyroid hormone levels.

\subsection{Statistical analysis}

All data were expressed as mean \pm standard deviation (SD). Differences between groups were assessed for statistical significance using the Student's $t$-test. All statistical analyses were performed with the SPSS 20.0 software (SPSS Inc., Chicago, IL, USA) and statistical significance was set at a two-tailed $P$ value of $<0.05$.

\section{Results}

\subsection{Body weight}

As expected for healthy rodents, mice in each group showed progressive weight gain from 21.0$23.5 \mathrm{~g}$ to $27.3-30.1 \mathrm{~g}$ over 5 weeks on the lithogenic diet (Fig. 2a). The average body weight of mice in the hypothyroidism group $((28.7 \pm 1.1) \mathrm{g})$ was significantly higher than that in the euthyroidism group $((25.2 \pm 0.8) \mathrm{g})$, with a $P$-value of $<0.01$, but the small difference between the hyperthyroidism group $((25.9 \pm 2.7) \mathrm{g})$ and the euthyroidism group (Fig. 2d) did not reach statistical significance. The average adipose tissue volume of mice in the hypothyroidism group was significantly higher than that in the euthyroidism group, with a $P$-value of $<0.05$; however, there was no significant difference between the hyperthyroidism and euthyroidism groups (data not shown). During the 8th to 14th days of feeding the lithogenic diet, the weight growth-rate (average weight gain per day) of mice in the hypothyroidism group $((0.09 \pm 0.05) \mathrm{g} / \mathrm{d})$ was significantly higher than that in the hyperthyroidism group $((-0.22 \pm 0.33) \mathrm{g} / \mathrm{d})$, with a $P$-value of $<0.05$; however, there was no 
significant difference between the euthyroidism $((0.07 \pm 0.09) \mathrm{g} / \mathrm{d})$ and hyperthyroidism groups (Fig. 2b). During the 25 th to 30 th days, the weight growth-rate of mice in the euthyroidism group $((-0.06 \pm 0.13) \mathrm{g} / \mathrm{d})$ was significantly lower than that in the hyperthyroidism $((0.25 \pm 0.31) \mathrm{g} / \mathrm{d})$ and hypothyroidism $((0.22 \pm 0.11) \mathrm{g} / \mathrm{d})$ groups, with $P$-values of $<0.05$ and $<0.01$, respectively (Fig. 2c).

\subsection{Serum cholesterol levels}

The serum cholesterol level of mice in the hypothyroidism group $((5.57 \pm 0.20) \mathrm{mmol} / \mathrm{L})$ was significantly higher than that in the euthyroidism group $((4.26 \pm 0.17) \mathrm{mmol} / \mathrm{L})$; however, there was no significant difference between the hyperthyroidism ( $4.03 \pm$ $0.16) \mathrm{mmol} / \mathrm{L}$ ) and euthyroidism groups (Fig. 2e).
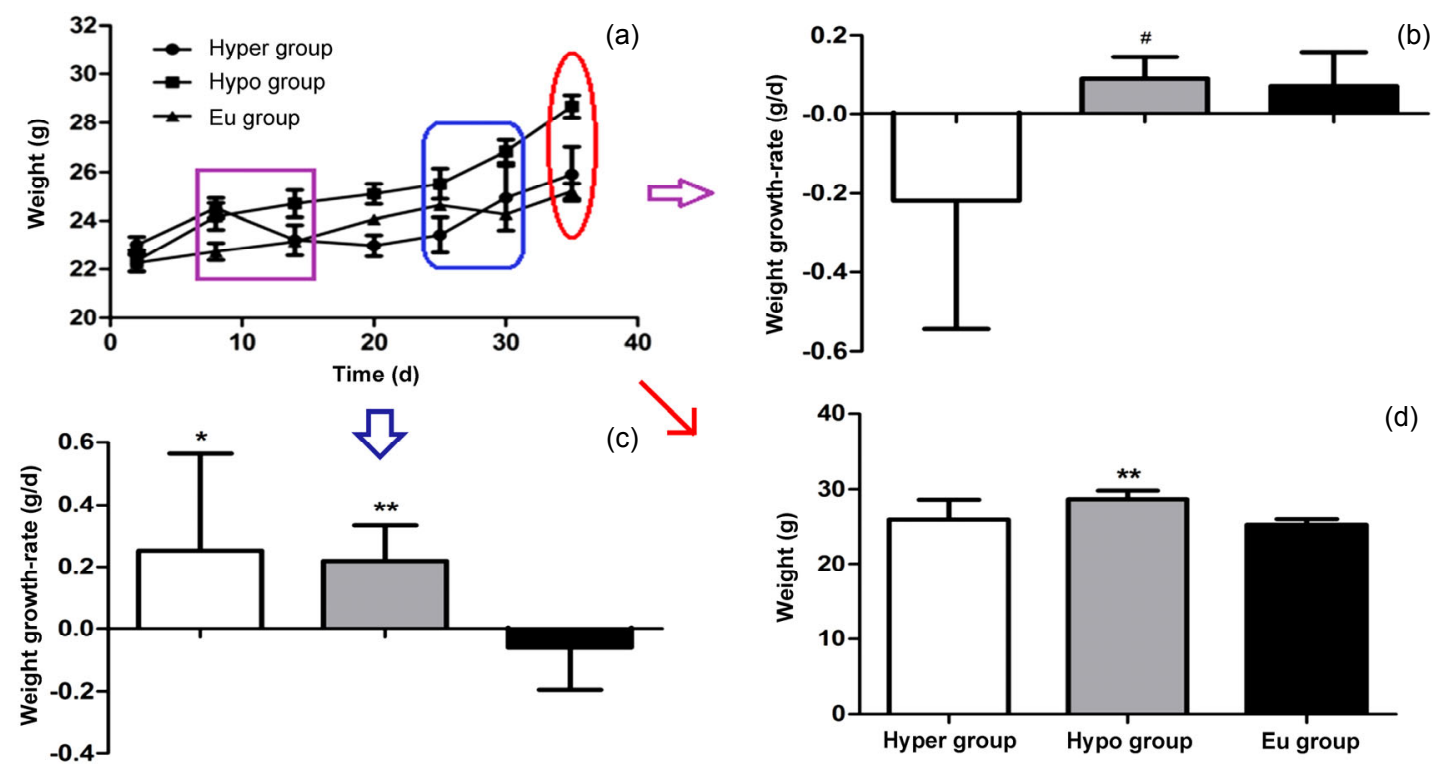

(e)

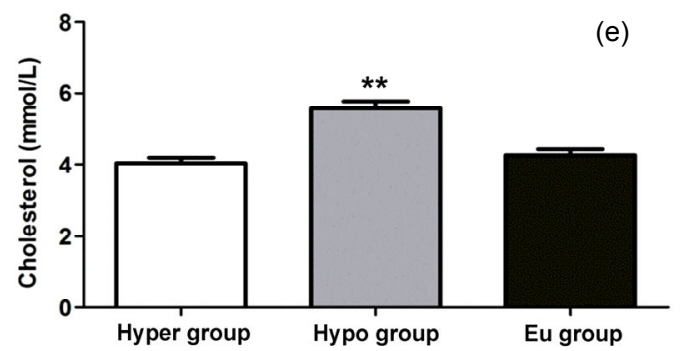

Fig. 2 Comparasion of body weight and serum cholesterol level of gonadectomized C57BL/6 male mice in hyperthyroidism, hypothyroidism, and euthyroidism groups

(a) Growth curves of average body weight of C57BL/6 mice feeding the lithogenic diet for 5 weeks. (b, c) Comparison of weight growth-rate of gonadectomized C57BL/6 male mice in hyperthyroidism, hypothyroidism, and euthyroidism groups, from the 8th to 14 th days and from the 25 th to 30 th days after feeding the lithogenic diet, respectively. (d, e) Comparison of body weight and serum cholesterol level of gonadectomized C57BL/6 male mice fed the lithogenic diet for $35 \mathrm{~d}$. All data are expressed as mean \pm SD ( $n=6$ animals in each group). ${ }^{*} P<0.05$ and ${ }^{* *} P<0.01$, when compared with the euthyroidism group; ${ }^{\#} P<0.05$, when compared with the hyperthyroidism group

\subsection{Serum thyroid hormones levels}

Serum thyroid hormone (TH) levels were determined to confirm that mouse models for hyperthyroidism, hypothyroidism, and euthyroidism had been successfully established. The T3, T4, and TSH levels of mice in the euthyroidism group were (11.9 \pm 1.0$) \mathrm{pmol} / \mathrm{L},(189.1 \pm 26.9) \mathrm{ng} / \mathrm{dl}$, and $(343.7 \pm$ 31.9) $\mu \mathrm{IU} / \mathrm{L}$, respectively. Compared with this group, the hyperthyroidism group showed significantly increased T3 $((52.3 \pm 1.1) \mathrm{pmol} / \mathrm{L})$ and T4 ((276.3 \pm 37.2) $\mathrm{ng} / \mathrm{dl}$ ) levels but significantly decreased TSH $((81.3 \pm 24.2) \mu \mathrm{IU} / \mathrm{L})$, with each $P$-value of $<0.01$; whereas, the hypothyroidism group showed significantly decreased T3 $((6.9 \pm 0.7) \mathrm{pmol} / \mathrm{L})$ and T4 $((64.2 \pm 13.7) \mathrm{ng} / \mathrm{dl})$ but increased TSH $((561.3 \pm$ 27.1) $\mu \mathrm{IU} / \mathrm{L}$ ), with each $P$-value of $<0.01$ (Fig. 1d). 


\subsection{Microscopic observations: examples of liquid and solid crystals}

Fig. 3 displays representative photomicrographs of mucin gel as well as examples of liquid crystals, solid cholesterol crystals, sandy stones, and true gallstones as observed in fresh gallbladder bile of gonadectomized C57BL/6 male mice by polarizing light microscopy. Mucin gel appeared as nonbirefringent amorphous strands (Fig. 3a). Liquid crystals were denoted as aggregated (Fig. 3b) when non-birefringent with particles of $1-5 \mu \mathrm{m}$ in size, and fused (Figs. 3c and 3d) when they displayed characteristic focal conic textures and Maltese-cross birefringence. Non-birefringent tubular crystals were also detected (Fig. 3e); they often appeared to fracture at their ends producing plate-like ChM crystals with a notched corner (Fig. 3f). Amorphous masses of ChM crystals were defined loosely as agglomerated sheets (Fig. 3g). Disintegrable amorphous sandy stones were embedded in mucin gel (Fig. 3h) and exhibited individual ChM crystals projecting from their edges (Fig. 3i). True gallstones exhibited typical round contours and black centers (Fig. 3j).

\subsection{Sequences of cholesterol gallstone formation}

To illustrate the sequences of gallstone formation, we observed cholesterol crystallization and gallstone formation in mice from each group for 10 weeks whilst they were fed the lithogenic diet (Table 1). At the end of the first week, a layer of mucin gel adherent to the gallbladder wall was observed in all six mice. At the end of the 2nd week, aggregated liquid crystals were detected (6/6). At the end of the 3rd week, typically fused liquid crystals with focal conic textures and Maltese-cross birefringence were found (4/6). At the end of the 4 th week, fused liquid crystals with circular around texture were observed (6/6). At the end of the 5th week, tubular crystals were observed (4/6), while circular liquid crystals began to disappear (2/6). At the end of the 6th week, classic plate-like ChM crystals were present (6/6) and amorphous ChM crystals were observed $(4 / 6)$. At the end of 8 th week, amorphous sandy stones were detected as surrounded by mucin gel with individual cholesterol crystals projecting from the edges. At the end of 10 th week, $100 \%$ of mice (6/6) formed true gallstones that exhibited rounded contours and black centers.
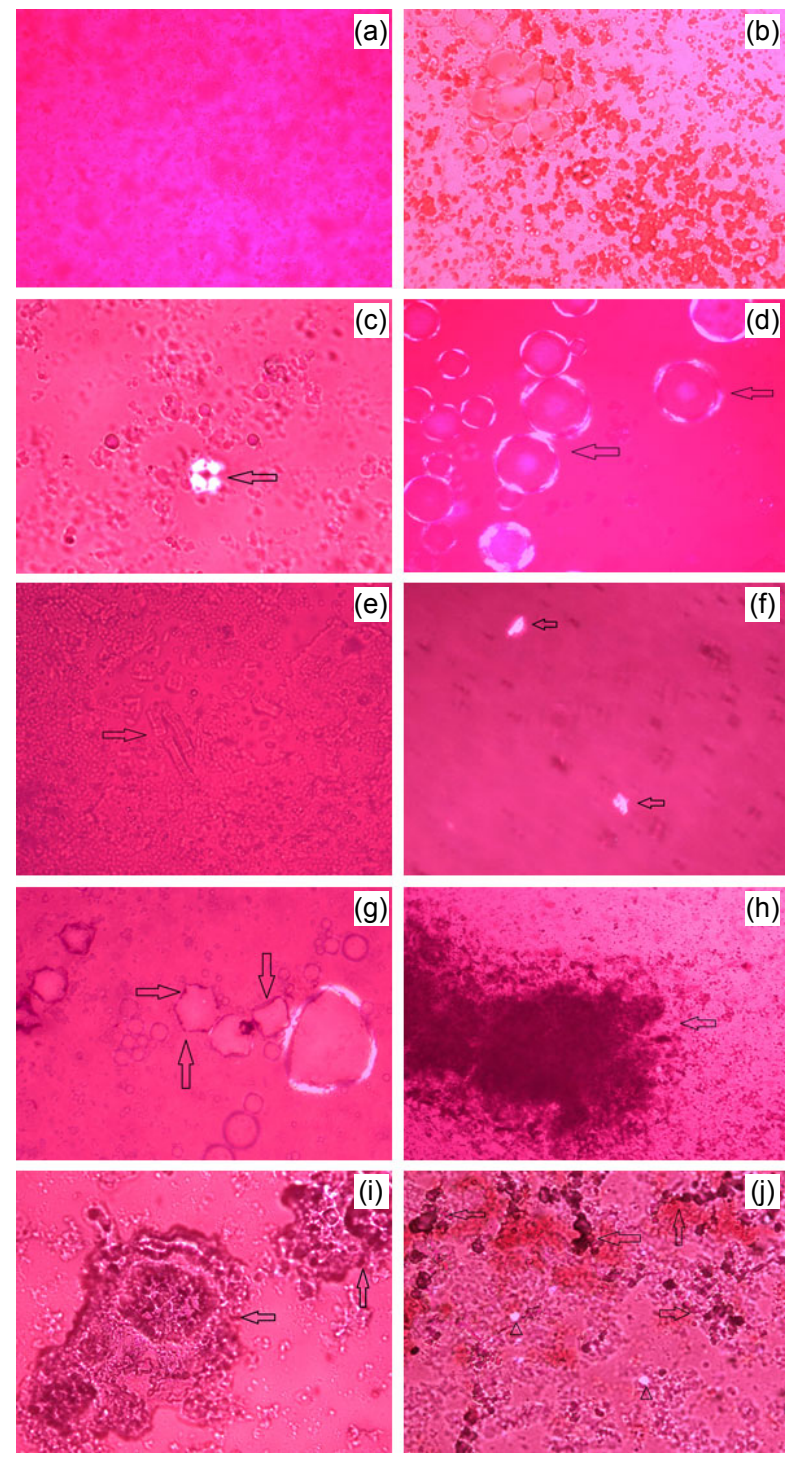

Fig. 3 Representative photomicrographs of mucin gel as well as examples of liquid crystals, solid cholesterol crystals, sandy stones, and true gallstones as observed in fresh gallbladder bile of gonadectomized C57BL/6 male mice using polarizing light microscopy

(a) Non-birefringent amorphous mucin gel; (b) Aggregated non-birefringent liquid crystals; (c) Typically fused liquid crystals with Maltese-cross birefringence and focal conic textures; (d) Aggregated birefringent liquid crystals with circular surrounded textures; (e) Scattered or aggregated non-birefringent tubular crystals; (f) Tubular crystals fracturing at their ends to produce plate-like cholesterol monohydrate crystals with a notched corner; (g) Agglomerated cholesterol monohydrate crystals; (h) Disintegrable amorphous sandy stones surrounded by mucin gel; (i) Disintegrable aggregated sandy stones exhibiting individual ChM crystals projecting from the edges; (j) Gallstones exhibiting round contours and black centers from light scattering/absorption. All magnifications are $200 \times$, except $3 \mathrm{c}, 3 \mathrm{f}, 3 \mathrm{i}$, and $3 \mathrm{j}$ which are $500 \times$, using polarizing light microscopy 


\subsection{Macroscopic and microscopic observations of gallbladders}

As shown in Fig. 4, gallbladder sizes were significantly larger in hyperthyroidism and hypothyroidism than in euthyroidism, after $35 \mathrm{~d}$ of a lithogenic diet. Gallbladder walls were thick and turbid in mice with hyperthyroidism and hypothyroidism, but thin and transparent in those with euthyroidism (Fig. 4a). Classic plate-like ChM crystals were detected using polarizing light microscopy in 6/6 of mice with hyperthyroidism, 5/6 with hypothyroidism, and 2/6 with euthyroidism. True gallstones were detected in hyperthyroidism (2/6) (Fig. 4b).

\subsection{Hepatic lithogenic gene expression analysis}

Fig. 5 demonstrates the expression levels of the eight crucial hepatic lithogenic genes in mice with hyperthyroidism, hypothyroidism, and euthyroidism. Mice with hypothyroidism showed up-regulation of $\operatorname{Tr} \beta$ and down-regulation of $\operatorname{Rxr}$ compared with mice with euthyroidism. Mice with hyperthyroidism showed up-regulation of $L x r \alpha, R x r$, and Cyp $7 \alpha 1$ and downregulation of Fxr compared with those with euthyroidism. However, Abcg5 and Abcg8 were neither up- nor down-regulated in mice with hyperthyroidism or hypothyroidism.

Table 1 Number of mice that developed cholesterol crystals/stones over 10 weeks when on the lithogenic diet

\begin{tabular}{ccccccccccc}
\hline Week & NMG & NLC & CLC1 & CLC2 & NTC & RCC & ACC & ASS1 & ASS2 & RGS \\
\hline 0 & $0 / 6$ & $0 / 6$ & $0 / 6$ & $0 / 6$ & $0 / 6$ & $0 / 6$ & $0 / 6$ & $0 / 6$ & $0 / 6$ & $0 / 6$ \\
1 & $6 / 6$ & $1 / 6$ & $0 / 6$ & $0 / 6$ & $0 / 6$ & $0 / 6$ & $0 / 6$ & $0 / 6$ & $0 / 6$ & $0 / 6$ \\
2 & $6 / 6$ & $6 / 6$ & $1 / 6$ & $0 / 6$ & $0 / 6$ & $0 / 6$ & $0 / 6$ & $0 / 6$ & $0 / 6$ & $0 / 6$ \\
3 & $6 / 6$ & $5 / 6$ & $4 / 6$ & $1 / 6$ & $0 / 6$ & $0 / 6$ & $0 / 6$ & $0 / 6$ & $0 / 6$ & $0 / 6$ \\
4 & $6 / 6$ & $6 / 6$ & $6 / 6$ & $6 / 6$ & $2 / 6$ & $0 / 6$ & $0 / 6$ & $0 / 6$ & $0 / 6$ & $0 / 6$ \\
5 & $6 / 6$ & $6 / 6$ & $5 / 6$ & $2 / 6$ & $4 / 6$ & $2 / 6$ & $0 / 6$ & $0 / 6$ & $0 / 6$ & $0 / 6$ \\
6 & $6 / 6$ & $5 / 6$ & $5 / 6$ & $1 / 6$ & $2 / 6$ & $6 / 6$ & $4 / 6$ & $0 / 6$ & $0 / 6$ & $0 / 6$ \\
8 & $6 / 6$ & $5 / 6$ & $6 / 6$ & $0 / 6$ & $1 / 6$ & $5 / 6$ & $5 / 6$ & $4 / 6$ & $3 / 6$ & $1 / 6$ \\
10 & $6 / 6$ & $6 / 6$ & $6 / 6$ & $0 / 6$ & $0 / 6$ & $6 / 6$ & $2 / 6$ & $1 / 6$ & $6 / 6$ & $6 / 6$ \\
\hline
\end{tabular}

Values are the number of mice out of 6 at each observation point. NMG, the number that developed non-birefringent mucin gel; NLC, non-birefringent liquid crystals; CLC1, conic liquid crystals; CLC2, circular liquid crystals; NTC, non-birefringent tubular crystals; RCC, representative ChM crystals; ACC, amorphous ChM crystals; ASS1, amorphous sandy stones; ASS2, agglomerated sandy stones; RGS, representative gallstones

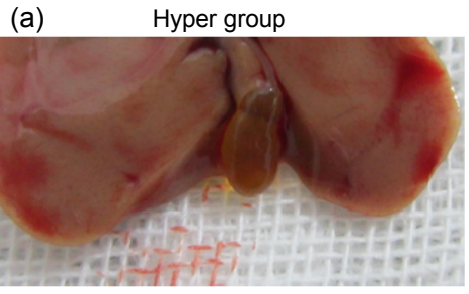

(b)

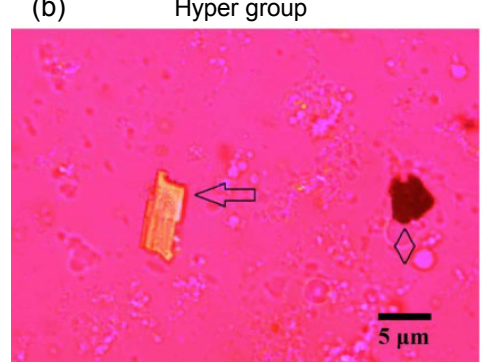

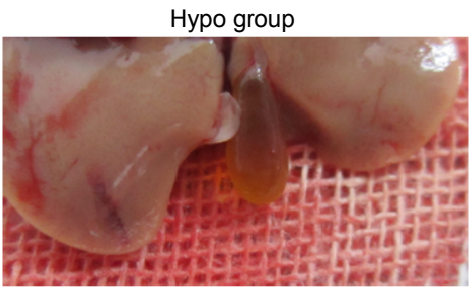

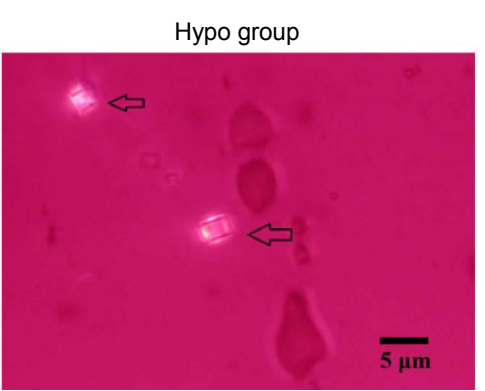

Eu group

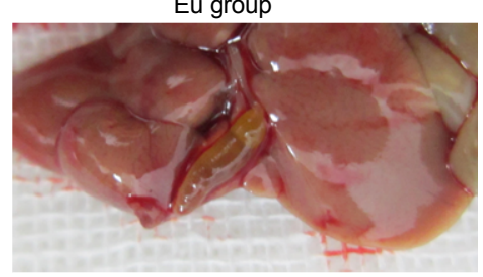

Eu group

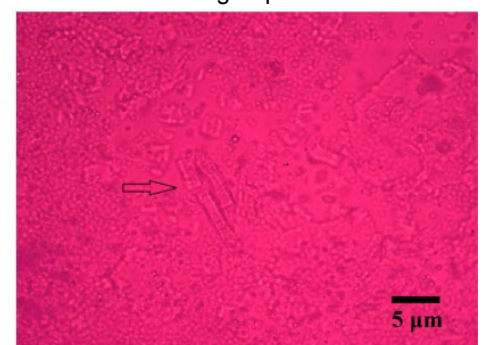

Fig. 4 Macroscopic (a) and microscopic (b) observations of bile liquid crystallization and gallstone formation in hyperthyroidism, hypothyroidism, and euthyroidism mice

In hyperthyroidism, both characteristic cholesterol monohydrate crystals (arrows) and gallstones (arris) can be found (6/6, 100\%). In hypothyroidism, only cholesterol monohydrate crystals can be detected (5/6, 83\%). In most mice with euthyroidism, non-birefringent tubular crystals can be detected, but cholesterol monohydrate crystals can only be observed in $2 / 6$ 

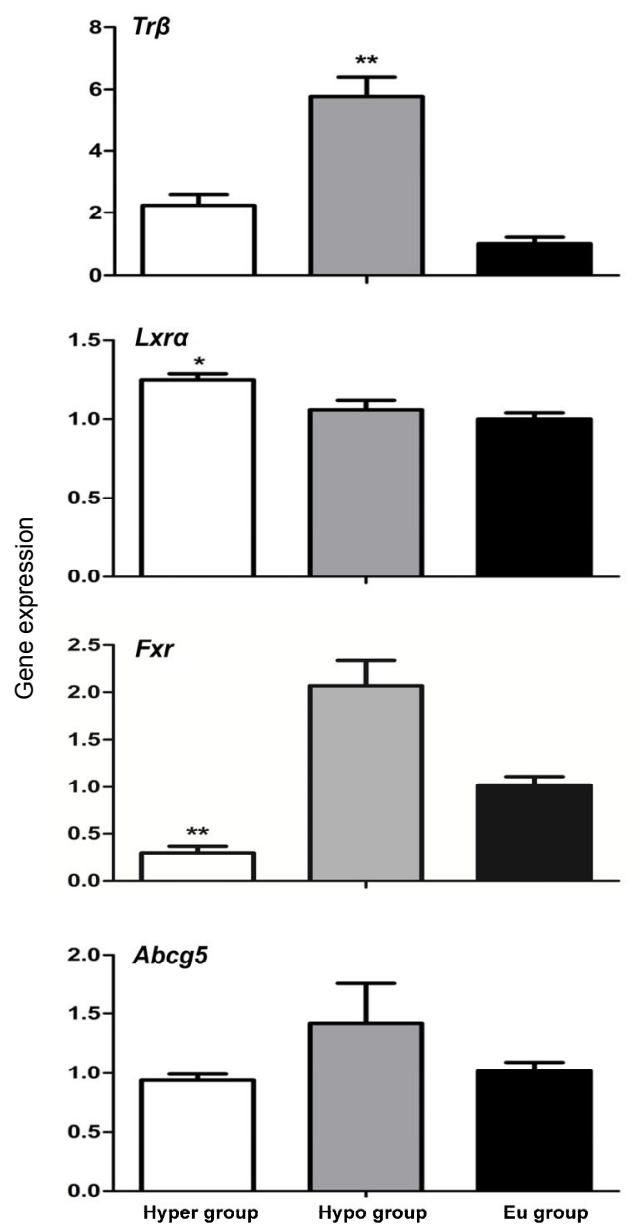

\section{Discussion}

The present study examined the function of THs on gallstone formation in vivo using an animal model. Gonadectomized gallstone-susceptible C57BL/6 mice were used to induce hypothyroidism, hyperthyroidism, or euthyroidism through surgery and medication. Afterwards, they were fed a well-established lithogenic diet to induce cholesterol crystals and gallstones. After $35 \mathrm{~d}$ on this diet, $100 \%$ of mice with hyperthyroidism, $83 \%$ of mice with hypothyroidism, but only $33 \%$ of those with euthyroidism developed ChM crystals, suggesting that thyroid dysfunction, either hyperthyroidism or hypothyroidism, promotes the formation of cholesterol gallstones in C57BL/6 mice. To the best of our knowledge, this is the first in vivo study demonstrating the contribution of hyperthyroidism to gallstone formation, and the first to use mouse models for hyperthyroidism, hypothyroidism, and euthyroidism to understand comprehensively the
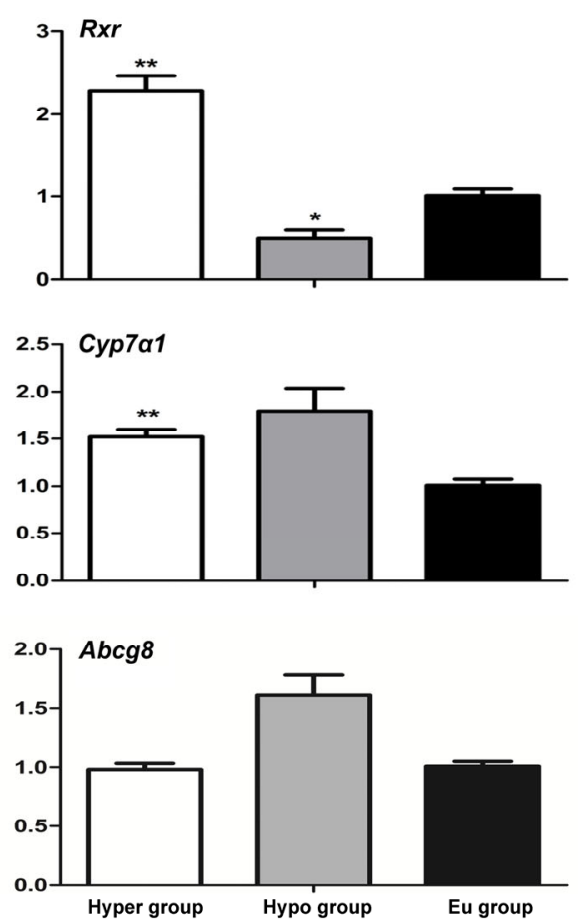

Fig. 5 Comparasion of expression levels of the eight major hepatic lithogenic genes in hyperthyroidism, hypothyroidism, and euthyroidism mice after feeding the lithogenic diet

All data are expressed as mean $\pm \mathrm{SD}(n=6$ animals in each group). ${ }^{*} P<0.05,{ }^{* *} P<0.01$, compared with euthyroidism group

role of thyroid hormones in the development of CGD. Hyperthyroidism had been found to be associated with lower total, LDL, and HDL cholesterol levels, and to promote the RCT pathway, thus protecting bodies from cholelithiasis. However, the present study shows that hyperthyroidism promotes the formation of cholesterol gallstones in vivo. This finding is supported by a case report of gallstones disappearing during treatment for toxic goiter with carbimazole and thyroxine (Vassilakis and Nicolopoulos, 1981). We can deduce that hyperthyroidism has some association with gallstone formation, and when it is corrected, gallstones disappear. Hypothyroidism has been shown to promote gallstone formation, which is consistent with previous studies (Cakir et al., 2009; Bonde et al., 2012).

We further investigated the underlying mechanism of thyroid dysfunction in contributing to cholesterol gallstone formation. Although both hyperthyroidism and hypothyroidism promote cholesterol 
gallstone formation, they work in totally different ways. Hyperthyroidism induces cholesterol gallstones through over-expression of hepatic nuclear receptor genes $L x r \alpha, R x r$, etc., which are major components in the cholesterol metabolism pathway. However, hypothyroidism induces cholesterol gallstones by promoting cholesterol biosynthesis.

As with most common diseases, CGD is believed to be multifactorially influenced by both genetic and environmental factors (Portincasa et al., 2006). The disturbance of bile cholesterol homeostasis is essential for cholesterol formation (Portincasa and Wang, 2012). Cholesterol supersaturation occurs when either too much cholesterol or not enough solubilizing bile salt and phosphatidylcholine molecules are secreted to allow complete micellar solubilization of all cholesterol (Venneman and van Erpecum, 2010). Hepatic secretion of biliary lipids is determined mainly by an elaborate network of adenosine triphosphate-binding cassette (ABC) transporters in the hepatocytic apical (canalicular) membrane that regulates biliary secretion and the relative concentration of bile salts, phosphatidylcholine, and cholesterol (Repa et al., 2002; Paulusma et al., 2009; Morita et al., 2013). Various receptors, including intrahepatocytic nuclear farnesoid $\mathrm{X}$ receptor (FXR), retinoid $\mathrm{X}$ receptor (RXR), and liver $\mathrm{X}$ receptor (LXR), have been found to regulate these $\mathrm{ABC}$ transporters. Nuclear receptor LXR $\alpha$ plays a crucial role in inducing expression of the hepatic canalicular membrane proteins for cholesterol transport (Hashimoto and Mori, 2011). FXR induces hepatic canalicular membrane proteins for bile salt and phosphatidylcholine transport (Moschetta et al., 2004). The LXR effect is mediated through a unique heterodimeric interaction with RXR (Germain et al., 2006).

In mice, Hashimoto et al. $(2006$; 2007) demonstrated that THs and thyroid receptor isoform $\beta$ (TR $\beta$ ) up-regulate $L x r \alpha$ through negative regulation of the sterol regulatory element-binding protein-1c gene (Srebp-1c) transcription. Another study also found that THs mediate the ABCG5/G8 complex to stimulate the secretion of cholesterol into bile (Bonde et al., 2012). Therefore, THs and TR $\beta$ must play a part in bile cholesterol homeostasis. In the present study, hyperthyroidism promotes CGD. Meanwhile, the hepatic gene expression of $L x r \alpha$ and $R x r$ were up-regulated and the expression of Fxr downregulated in mice with hyperthyroidism. THs may have stimulated gallstone formation in hyperthyroidism, by up-regulating Lxr and Rxr and downregulating $F x r$, resulting in stimulation of canalicular membrane transporters which induce cholesterol transport but inhibit bile salt and phosphatidylcholine transport. The up-regulation of LXR/RXR and downregulation of FXR/RXR mediate over-expression of the cholesterol $7 \alpha$-hydroylase gene $(C y p 7 \alpha 1)$. As illustrated schematically in Fig. 6, phosphatidylcholinecholesterol-bile salt molecules have been formed through transport proteins (ABC-B11, ABC-B4, and

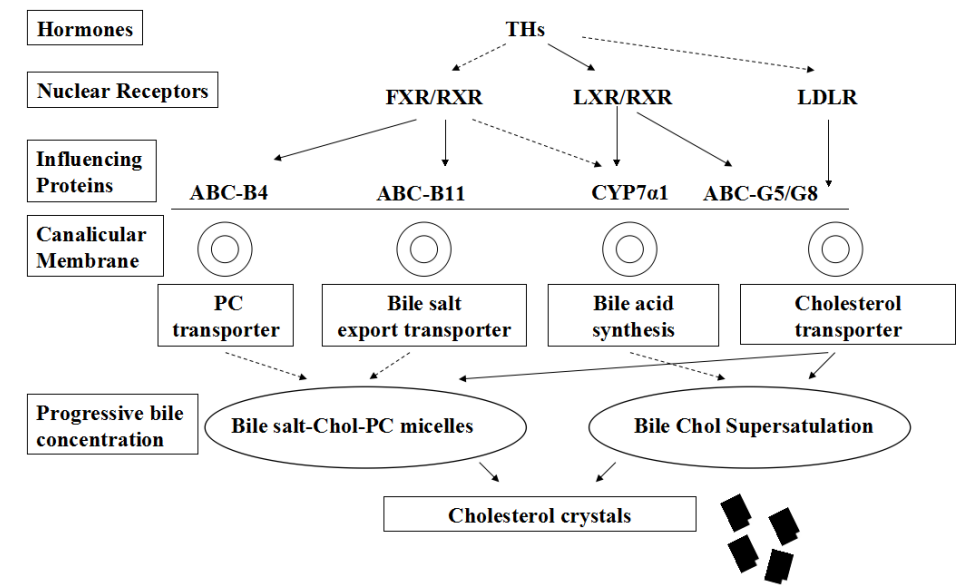

Fig. 6 Schematic diagram of the mechanism of THs regulating gallstone formation in vivo

FXR/RXR heterodimers which mediate phosphatidylcholine and bile salt transporters (ABC-B4 and ABC-B11) are down-regulated by THs. THs up-regulate LXR/RXR heterodimers thus affecting sterol efflux transporters (ABC-G5/G8). CYP7 $\alpha 1$ (the limiting enzyme of bile acid synthesis pathway) is mediated indirectly by THs through up-regulation of LXR/RXR and down-regulation of FXR/RXR heterodimers. THs correspond to a decrease in the serum cholesterol level and down-regulation of hepatic LDLR (low-density lipoprotein receptors). Chol, cholesterol; PC, phosphatidylcholine; solid line, up-regulation; dashed line, down-regulation 
ABC-G5/G8) in the hepatocyte canalicular membrane. Although bile acid synthesis is increased because of increased Cyp $7 \alpha 1$ expression, the increase of bile cholesterol supersaturation is detected because of the function of the ABCG5/G8 complex. Those two steps contribute to cholesterol crystallization and gallstone formation. As a consequence, serum cholesterol level is lower in the hyperthyroidism group, but THs play a role in stimulating gallstone formation.

Interestingly, THs deficiency also promotes gallstone formation in C57BL/6 mice. In hypothyroidism, expression of the hepatic Abcg8 gene was significantly up-regulated. However, no significant differences were found in the expression of $\mathrm{Abcg} 5$, Lxr $\alpha, F x r$, or Rxr between hypothyroidism and euthyroidism. The average body weight and adipose tissue volume of mice with hypothyroidism were significantly higher than those in mice with euthyroidism or hyperthyroidism after $35 \mathrm{~d}$ on the lithogenic diet (Fig. 2d). In summary, mice with hypothyroidism tend to gain weight easily and overproduce cholesterol. As a result, THs deficiency promotes gallstone formation in gonadectomized male C57BL/6 mice. In conclusion, thyroid hormone levels are associated with the risk of cholesterol crystallization and gallstone formation in vivo.

\section{Conclusions}

The most important conclusion from our study is that, when treating patients with gallstones or microlithiasis, clinicians may be aware of the possibility of thyroid dysfunction, although the clinical significance of a link between hyperthyroidism and CGD warrants further study. In addition, large-scale studies should be expected to confirm the associations in human beings.

\section{Compliance with ethics guidelines}

Yong WANG, Xing YU, Qun-zi ZHAO, Shu ZHENG, Wen-jie QING, Chun-di MIAO, and Jaiswal SANJAY declare that they have no conflict of interest.

All institutional and national guidelines for the care and use of laboratory animals were followed.

\section{References}

Admirand, W.H., Small, D.M., 1968. The physicochemical basis of cholesterol gallstone formation in man. J. Clin. Invest., 47(5):1043-1052.
http://dx.doi.org/10.1172/JCI105794

Attili, A.F., Carulli, N., Roda, E., et al., 1995. Epidemiology of gallstone disease in Italy: prevalence data of the multicenter Italian study on cholelithiasis (M.I.COL.). Am. J. Epidemiol., 141(2):158-165.

Attili, A.F., Capocaccia, R., Carulli, N., et al., 1997. Factors associated with gallstone disease in the micol experience. Multicenter Italian study on epidemiology of cholelithiasis. Hepatology, 26(4):809-818. http://dx.doi.org/10.1002/hep.510260401

Bonde, Y., Plosch, T., Kuipers, F., et al., 2012. Stimulation of murine biliary cholesterol secretion by thyroid hormone is dependent on a functional ABCG5/G8 complex. Hepatology, 56(5):1828-1837. http://dx.doi.org/10.1002/hep.25861

Cakir, M., Kayacetin, E., Toy, H., et al., 2009. Gallbladder motor function in patients with different thyroid hormone status. Exp. Clin. Endocrinol. Diabetes, 117(8):395-399. http://dx.doi.org/10.1055/s-0029-1202850

Diehl, A.K., 1991. Epidemiology and natural history of gallstone disease. Gastroenterol. Clin. North Am., 20(1):1-19.

Duntas, L.H., 2002. Thyroid disease and lipids. Thyroid, 12(4): 287-293. http://dx.doi.org/10.1089/10507250252949405

Galman, C., Bonde, Y., Matasconi, M., et al., 2008. Dramatically increased intestinal absorption of cholesterol following hypophysectomy is normalized by thyroid hormone. Gastroenterology, 134(4):1127-1136. http://dx.doi.org/10.1053/j.gastro.2008.01.032

Germain, P., Chambon, P., Eichele, G., et al., 2006. International union of pharmacology. LXIII. Retinoid X receptors. Pharmacol. Rev., 58(4):760-772. http://dx.doi.org/10.1124/pr.58.4.7

Gililland, K.R., Finn, D.A., 2007. The impact of gonadectomy and adrenalectomy on acute withdrawal severity in male and female C57BL/6J and DBA/2J mice following a single high dose of ethanol. Alcohol. Clin. Exp. Res., 31(11): 1846-1857. http://dx.doi.org/10.1111/j.1530-0277.2007.00509.x

Hashimoto, K., Mori, M., 2011. Crosstalk of thyroid hormone receptor and liver $\mathrm{X}$ receptor in lipid metabolism and beyond. Endocr. J., 58(11):921-930. http://dx.doi.org/10.1507/endocrj.EJ11-0114

Hashimoto, K., Yamada, M., Matsumoto, S., et al., 2006. Mouse sterol response element binding protein-1c gene expression is negatively regulated by thyroid hormone. Endocrinology, 147(9):4292-4302. http://dx.doi.org/10.1210/en.2006-0116

Hashimoto, K., Matsumoto, S., Yamada, M., et al., 2007. Liver $\mathrm{X}$ receptor- $\alpha$ gene expression is positively regulated by thyroid hormone. Endocrinology, 148(10):4667-4675. http://dx.doi.org/10.1210/en.2007-0150

Inkinen, J., Sand, J., Arvola, P., et al., 2001. Direct effect of thyroxine on pig sphincter of Oddi contractility. Dig. Dis. Sci., 46(1):182-186. http://dx.doi.org/10.1023/A:1005674211976

Khanuja, B., Cheah, Y.C., Hunt, M., et al., 1995. Lith1, a major gene affecting cholesterol gallstone formation among inbred strains of mice. PNAS, 92(17):7729-7733. 
http://dx.doi.org/10.1073/pnas.92.17.7729

Laukkarinen, J., Sand, J., Aittomaki, S., et al., 2002. Mechanism of the prorelaxing effect of thyroxine on the sphincter of Oddi. Scand. J. Gastroenterol., 37(6):667-673. http://dx.doi.org/10.1080/00365520212492

Laukkarinen, J., Sand, J., Saaristo, R., et al., 2003. Is bile flow reduced in patients with hypothyroidism? Surgery, 133(3): 288-293. http://dx.doi.org/10.1067/msy.2003.77

Morita, S.Y., Tsuda, T., Horikami, M., et al., 2013. Bile salt-stimulated phospholipid efflux mediated by ABCB4 localized in nonraft membranes. J. Lipid Res., 54(5): 1221-1230. http://dx.doi.org/10.1194/jlr.M032425

Moschetta, A., Bookout, A.L., Mangelsdorf, D.J., 2004. Prevention of cholesterol gallstone disease by FXR agonists in a mouse model. Nat. Med., 10(12):1352-1358. http://dx.doi.org/10.1038/nm1138

Paulusma, C.C., de Waart, D.R., Kunne, C., et al., 2009. Activity of the bile salt export pump (ABCB11) is critically dependent on canalicular membrane cholesterol content. J. Biol. Chem., 284(15):9947-9954. http://dx.doi.org/10.1074/jbc.M808667200

Pedrelli, M., Pramfalk, C., Parini, P., 2010. Thyroid hormones and thyroid hormone receptors: effects of thyromimetics on reverse cholesterol transport. World J. Gastroenterol., 16(47):5958-5964.

Portincasa, P., Wang, D.Q., 2012. Intestinal absorption, hepatic synthesis, and biliary secretion of cholesterol: where are we for cholesterol gallstone formation? Hepatology, 55(5):1313-1316. http://dx.doi.org/10.1002/hep. 25604

Portincasa, P., Moschetta, A., Palasciano, G., 2006. Cholesterol gallstone disease. Lancet, 368(9531):230-239. http://dx.doi.org/10.1016/S0140-6736(06)69044-2

Repa, J.J., Berge, K.E., Pomajzl, C., et al., 2002. Regulation of ATP-binding cassette sterol transporters ABCG5 and ABCG 8 by the liver X receptors $\alpha$ and $\beta$. J. Biol. Chem., 277(21):18793-18800. http://dx.doi.org/10.1074/jbc.M109927200

Ros, E., Navarro, S., Bru, C., et al., 1991. Occult microlithiasis in 'idiopathic' acute pancreatitis: prevention of relapses by cholecystectomy or ursodeoxycholic acid therapy. Gastroenterology, 101(6):1701-1709. http://dx.doi.org/10.1016/0016-5085(91)90410-M

Tepperman, J., Caldwell, F.T., Tepperman, H.M., 1964. Induction of gallstones in mice by feeding a cholesterolcholic acid containing diet. Am. J. Physiol., 206:628-634.

van Erpecum, K.J., Wang, D.Q., Lammert, F., et al., 2001. Phenotypic characterization of lith genes that determine susceptibility to cholesterol cholelithiasis in inbred mice: soluble pronucleating proteins in gallbladder and hepatic biles. J. Hepatol., 35(4):444-451. http://dx.doi.org/10.1016/S0168-8278(01)00173-8

Vassilakis, J.S., Nicolopoulos, N., 1981. Dissolution of gallstones following thyroxine administration. A case report. Hepatogastroenterology, 28(1):60-61.

Venneman, N.G., van Erpecum, K.J., 2010. Pathogenesis of gallstones. Gastroenterol. Clin. North Am., 39(2):171-183. http://dx.doi.org/10.1016/j.gtc.2010.02.010
Volzke, H., Robinson, D.M., John, U., 2005. Association between thyroid function and gallstone disease. World $J$. Gastroenterol., 11(35):5530-5534. http://dx.doi.org/10.3748/wjg.v11.i35.5530

Wang, D.Q., Carey, M.C., 1996. Complete mapping of crystallization pathways during cholesterol precipitation from model bile: influence of physical-chemical variables of pathophysiologic relevance and identification of a stable liquid crystalline state in cold, dilute and hydrophilic bile salt-containing systems. J. Lipid Res., 37(3):606-630.

Wang, D.Q., Paigen, B., Carey, M.C., 1997. Phenotypic characterization of lith genes that determine susceptibility to cholesterol cholelithiasis in inbred mice: physicalchemistry of gallbladder bile. J. Lipid Res., 38(7): 1395-1411

Wang, Y., Jiang, Z.Y., Fei, J., et al., 2007. ATP binding cassette G8 T400K polymorphism may affect the risk of gallstone disease among Chinese males. Clin. Chim. Acta, 384(1-2):80-85.

http://dx.doi.org/10.1016/j.cca.2007.06.004

\section{中文概要}

题 目: 甲状腺功能失调促进胆囊结石形成的机制研究

目 的: 探究甲状腺功能失调 (包括功能六进或减退) 对 胆囊结石形成的影响, 并初步探讨其作用机制。

创新点: 首次在胆囊结石小鼠模型中证实甲状腺功能失调 (包括功能元进或减退) 将促进胆囊结石的形 成，且此作用通过不同的分子调控机制。

方 法: 应用性腺切除 C57BL/6 雄鼠构建胆囊结石动物模 型, 给予高脂饮食, 分别观察饲养 $0 、 1 、 2 、 3 、$ 4、5、6、8、10 周后胆囊结石形成情况。设置对 照组(假手术+磷酸缓冲盐溶液 (PBS) 皮下注射)、 甲状腺功能六进组 (假手术+三碘甲状腺原氨酸

(T3) 皮下注射) 和甲状腺功能减退组 (甲状腺 次全切除+PBS 皮下注射）, 给予高脂饮食 5 周, 观察胆囊结石形成情况, 收集肝脏组织用于测定 核受体表达水平。用苏木精-伊红染色法 (H\&E) 确定甲状腺切除, 用酶联免疫吸附测定 (ELISA) 试剂盒检测血液甲状腺激素水平, 用实时定量聚 合酶链式反应（RT-PCR）测定肝脏核受体表达 水平。

结 论: 本实验通过观察高脂饮食不同时间阶段小鼠胆囊 结石形成情况证实胆结石动物模型的构建成功 （表 1 和图 3）。ELISA 实验结果显示, 已成功 构建甲状腺功能六进和减退动物模型（图 1)。 甲状腺功能立进通过上调核受体 Lxr $、$ 、 R x r 和 Cyp 7 al, 下调 Fxr 表达而促进胆囊结石形成; 甲 状腺功能减退通过提高血清胆固醇水平以及下 调 $R x r$ 表达促进胆囊结石形成（图 4 和 5)。综 上所述, 甲状腺功能失调 (包括甲状腺功能六进 和减退) 通过不同的分子作用机制促进胆囊结石 的形成。

关键词: 甲状腺; 功能失调; 胆囊结石; 胆固醇; 核受体 